\title{
Blumenavia angolensis (Clathraceae), a rare phalloid reported from Northeastern Brazil
}

\section{Rodrigues $\mathrm{ACM}^{1}$ and Baseia IG $^{2}$}

\author{
${ }^{l}$ Programa de Pós Graduação em Sistemática e Evolução, Centro de Biociências, Universidade Federal do Rio \\ Grande do Norte, Campus Universitário, 59072-970, Natal, RN, Brazil (clarissa.ana@gmail.com) \\ ${ }^{2}$ Departamento de Botânica, Ecologia e Zoologia, Universidade Federal do Rio Grande do Norte, Campus \\ Universitário, 59072-970, Natal, RN, Brazil (baseia@cb.ufrn.br)
}

Rodrigues ACM, Baseia IG 2013 - Blumenavia angolensis (Clathraceae), a rare phalloid reported from Northeastern Brazil. Mycosphere 4(6), 1066-1069, Doi 10.5943/mycosphere/4/6/4

\begin{abstract}
Recent studies in the Atlantic Forest in Northeastern Brazil revealed a rare species, Blumenavia angolensis that is fundamentally distinguished by its black peridium and yellowish white receptacle with membranous glebifers. Description, comments and comparison with similar species, photograph of the fresh basidiomata, and SEM photographs of basidiospores are given. This is the first report of the genus Blumenavia from Northeastern Brazil.
\end{abstract}

Key words - Basidiomycota - Gasteromycetes - Neotropics - Phallales - Taxonomy

\section{Introduction}

The order Phallales was established by Fischer (1898-99) and comprises two families: Clathraceae and Phallaceae. Clathraceae was proposed by Chevallier (1926) and consists of latticed fungi, with receptacle composed of spongy, tubular and hollow arms. According to Pegler \& Goméz (1994) this family consists of twelve genera, including the genus Blumenavia. Clathraceae was emended by Cabral et al. (2012) that proposed a new genus, Abrachium (Baseia \& Calonge) Baseia \& T.S. Cabral and the lack of arms led an emendation in this family.

The genus Blumenavia was originally described from Santa Catarina state, Brazil (Möller $1895)$ based on B. rhacodes Möller. The occurrence of Blumenavia in Brazil is not common, consisting of a few records from the south of the country. Recently, López \& García (2001, 2012) reported $B$. rhacodes from Mexico, expanding the distributional area of this group. Only two species, B. rhacodes and B. angolensis (Welw. \& Curr.) Dring, were considered in this genus by Dring (1980). A third species, B. toribiotalpaensis Vargas-Rodriguez was described recently from Mexico (Vargas \& Vazquéz 2005).

Blumenavia is segregated from the close genera Clathrus P. Micheli ex L. fundamentally by the membranous glebifers attached by one side to each of the two inner angles of the column (Dring 1980, Sáenz 1980). Given the lack of information on the species richness of this noteworthy group of gasteroid fungi, our aim was to expand knowledge of this genus in a native area of Northeast Brazil.

\section{Materials \& Methods}

Collections were made in July 2012 at the Área de Proteção Ambiental (APA) of Serra de Baturité (S 04 $08^{\circ}-04^{\circ} 30^{\prime}$; W 38 $58^{\circ}-39^{\circ} 05^{\prime}$ ), located in Ceará state. Basidiomata were examined 

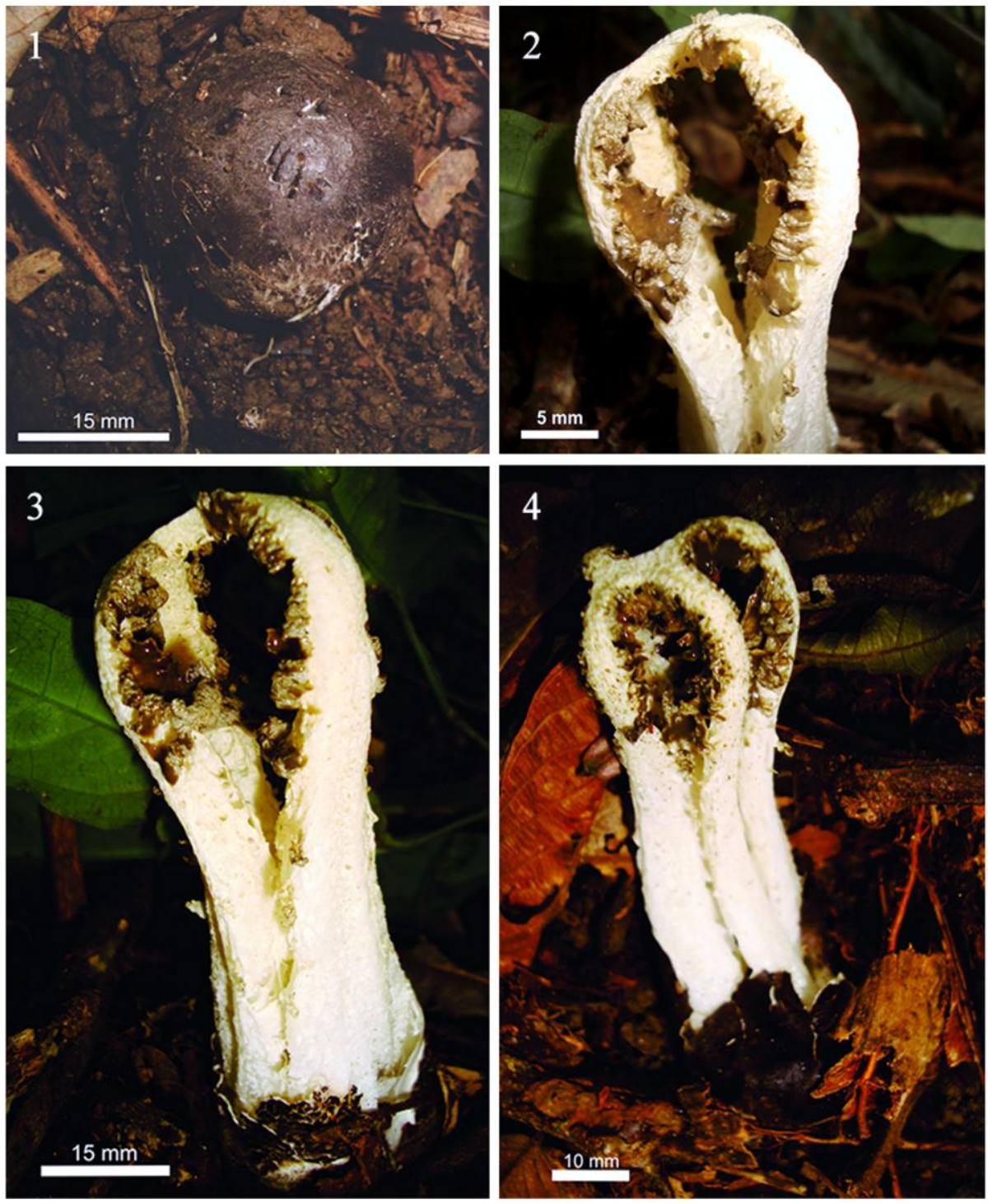

Figs 1-4 - Blumenavia angolensis. 1 Unexpanded basidioma. 2 View of glebifer; 3, 4. Mature basidioma. This picture is copyright of Ana Clarissa Moura Rodrigues.

and photographed in the field. Color determination was referenced according to Kornerup \& Wanscher (1978). Macroscopic and microscopic studies were based on Dring (1980) and Lopez et al. (1981). Collections were deposited in the UFRN herbarium.

\section{Results}

Blumenavia angolensis (Welw. \& Curr) Dring., Kew Bull. 35(1): 53 (1980)

Figs $1-8$

Immature globose basidioma, $27 \mathrm{~mm}$ in diameter, exoperidium black, basal portion attached to a thick, white rhizomorph. Receptacle fragile, spongy, urceolate, 83-91 mm high $\times 30-35 \mathrm{~mm}$ wide, ranging from yellowish white (KW 1A2) when fresh and grayish yellow (KW 4B4) to orange (KW 5B4) when dry, expanding into four anastomosed arms at the apex; arms exhibiting small perforations and locules. Gleba brown (KW 6E4) and dark brown (KW 6F4) when fresh, to black (KW 6F1) when dry, spread over the glebifers. Glebifer membranous, surface wrinkled, located on the upper part of the arms and attached to the inner lateral portions.

Basidiospores bacilliform, 3.1-3.6 $\mu \mathrm{m}$ long $\times 1 \mu \mathrm{m}$ wide, hyaline in $\mathrm{KOH}(5 \%)$, smooth, exhibiting two gutules at each end. Receptacle exhibiting globose to subglobose cells, $17.8-33 \mu \mathrm{m}$ $\times 11.4-27.9 \mu \mathrm{m}$, hyaline. Glebifer displaying globose to subglobose and ovoid cells, $8.7-21.4 \mu \mathrm{m} \times$ 8.2-19.4 $\mu \mathrm{m}$, hyaline. Volva composed of filamentous hyphae. 
Known distribution - Africa (Dring 1980, Degreef et al. 2013); Caribbean (Dring 1980); North America (Metzler et al. 1992); South America (Dring 1980, Bononi et al. 1981, Meijer 2006).

Material examined - Brazil, Ceará, Guaramiranga, Track of Veadeiros, S 04² $15^{\prime} 18.8^{\prime \prime}$ W 38 55'52.3', 865 m, 07 Jul 2012, A.C.M. Rodrigues \& T.L.D. Silva, UFRN - Fungos 1943.

\section{Discussion}

The specimens analysed have similar characteristics to those observed in Blumenavia angolensis (Welw. \& Curr) Dring, such as immature basidiomata with black peridium and yellowish white receptacle, in addition to the presence of membranous glebifers, attached laterally to the upper part of the arms. When our specimens are compared with $B$. rhacodes, considerable differences can be seen, such as the shape of the egg, which is ellipsoid in B. rhacodes and globose in our specimens. Furthermore, the receptacle is orangish and striate in $B$. rhacodes, which does not occur in the specimens studied. Other differences include the shape of the tubes inside the receptacle, which are triangular and trapezoid in B. rhacodes and circular in our specimens. The glebifers in the specimens studied are distributed only on the upper portion of the arms, a trait present in B. angolensis. Blumenavia toribiotalpaensis Vargaz-Rodriguez, a species described for Mexico (Vargas \& Vazquéz 2005), exhibits very similar characters to those of $B$. rhacodes, and is considered a synonym of this species by a number of authors (López \& García 2012).

Dring (1980) cites some subtle differences between the African and South American species of Blumenavia angolensis, such as egg colour and spore size. The African specimens of $B$. angolensis display slightly larger spores $(6 \mu \mathrm{m} \times 2 \mu \mathrm{m})$ when compared to the South American specimens $(3-3.5 \mu \mathrm{m} \times 1.5 \mu \mathrm{m})$. The spores of the specimens analysed in the present study have the same dimensions as those described in South American species by Dring (1980) and Degreef et al. (2013). Thus, our specimens lie within the concept of Blumenavia angolensis. This is the first record of the genus for Northeast Brazil and the third of B. angolensis for South America.
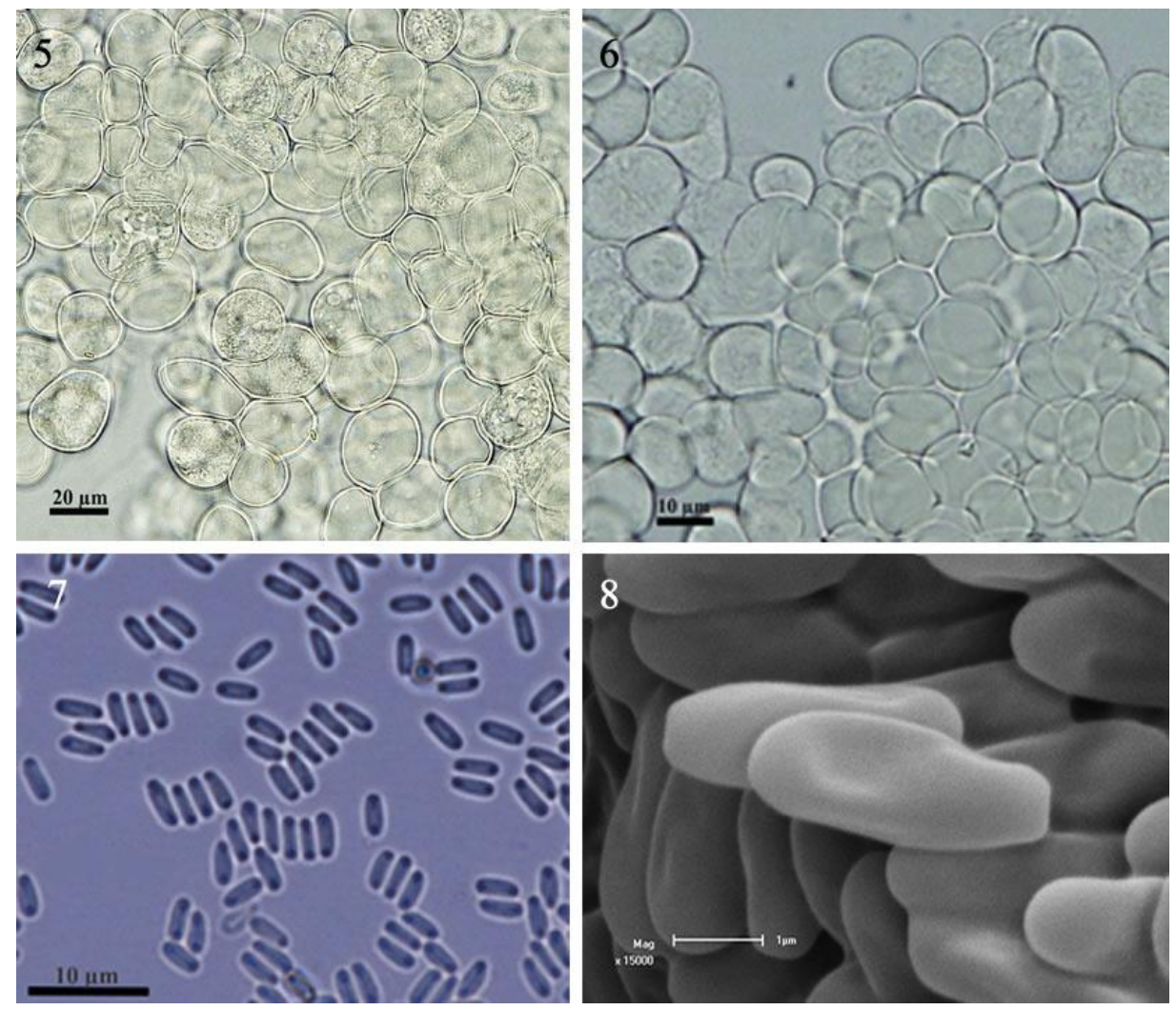

Figs 5-8 - Microscopic characteristics. 5 Receptacle cells. 6 Glebifer cells. 7 Spores under light microscope. 8 Spores under SEM. This picture is copyright of Ana Clarissa Moura Rodrigues. 


\section{Acknowledgements}

The authors are grateful the Semiarid Biodiversity Program (PPBio Semiárido/CNPq) for financial support and PROTAX CNPq/CAPES for providing Master scholarships to Ana Clarissa de Moura Rodrigues.

\section{References}

Bononi VLR, Trufem SFB, Grandi RAP. 1981 - Fungos macroscópicos do Parque Estadual das Fontes do Ipiranga depositados no Herbário do Instituto de Botânica. Rickia 9, 37-53.

Cabral TS, Marinho P, Goto B, Baseia IG. 2012 - Abrachium, a new genus in the Clathraceae, and Itajahya reassessed. Mycotaxon 119, 419-429.

Chevallier FF. 1826 - Flore Générale des Environs de Paris. $2^{\text {nd }}$ ed. Libraire Editéur, Paris.

Degreef J, Amalfi M, Decock C, Demoulin V. 2013 - Two rare Phallales recorded from São Tomé. Cryptogamie Mycologie 34, 3-13.

Dring DM. 1980 - Contributions towards a rational arrangement of the Clathraceae. Kew Bulletin $35,1-96$.

Fischer E. 1898-99 ["1900"] - Phallineae. In: Engler A, Prantl K (eds). Die natürlichen Pflanzenfamilien, Teil. Abteilung. Leipzig. 1, pp. 276-296.

Kornerup A, Wanscher JH. 1978 - Methuen Handbook of Colours. $3^{\text {th }}$ ed. Eyre Methuen, London, 252.

López A, Martínez D, García J. 1981 - Adiciones al conocimiento de los Phallales del estado de Veracruz. Boletín de la Sociedad Mexicana de Micología 16, 109-116.

López A, García, J. 2001 - Blumenavia rhacodes. Funga Veracruzana 33, 1-2.

López A, García, J. 2012 - Blumenavia rhacodes II. Funga Veracruzana 134, 1-2.

Meijer AAR. 2006. - Preliminary list of the macromycetes from the Brazilian State of Paraná. Boletim do Museu Botânico Municipal (Curitiba) 68, 1-55.

Metzler S, Metzler V, Miller Jr. OK. 1992 - Texas mushrooms. University of Texas Press 1, 1350.

Möller A. 1895 - Brasilische Pilzblumen. Bot. Mitth. Tropen 7, 1-152.

Pegler DN, Gomez LD. 1994 - An usual member of the cage fungus family. Mycologist 8, 54-59.

Sáenz JA. 1980 - Ligiella, a new genus for the Clathraceae. Mycologia 72, 338-349.

Vargas YL, Vázquez JA. 2005 - Blumenavia toribiotalpaensis: a new species of Clathraceae from Jalisco, Mexico. Mycotaxon 94, 7-14. 